\title{
Produktivitas Ayam Arab Petelur dengan Pola Pemberian Free Feeding Choice
}

\section{Productivity of Arab's Laying Hens with Free Feeding Choice}

\author{
Eudia Christina Wulandari ${ }^{1}$, Nefasa A. $\mathrm{N}^{1}$ \\ ${ }^{1}$ Fakultas Peternakan, Jurusan Peternakan, Universitas Boyolali \\ eudia1990.christina@gmail.com
}

\begin{abstract}
The aim of the present research was to evaluate the contribution effect of feeding Wulandari et al. (2013) and Wulandari et al. (2015) rations and free feeding choice in Arab hen. One hundred birds of Arab hen, age was \pm 14 weeks, with an average body weight of $814,73 \mathrm{~g} \pm 46,86 \mathrm{~g}$ were used as experimental animals, and were divided randomly into a randomized block design with 3 treatments and 6 replications. Feedstuffs used for dietary treatments were rice bran, yellow corn, fish meal, Azolla microphylla, $\mathrm{CaCO}_{3}$, oyster shell, meat bone meal, soybean meal, pollard, and top mix. The rations were formulated as ration from Wulandari et al. (2013) and Wulandari et al. (2015). At the same time, there are feedstuff which gived ad libitum without formulated. Conclusion of the research is that free feeding choice affect by palatability feedstuff and gives a random data. Consumption ration on free feeding choice more decrease than another treatments.
\end{abstract}

Keywords: arab's laying hans, free feeding choice, productivity

\section{PENDAHULUAN}

Indonesia terbentang dari Sabang sampai Merauke. Indonesia terdiri dari beribu-ribu pulau dengan kekayaan alam yang tak ternilai jumlahnya. Kekayaan ini tersusun atas keragaman biota alam darat dan laut, baik tumbuhan maupun hewan. Saat ini, keragaman hewan cukup menjadikan salah satu daya tarik peneliti, khususnya dunia peternakan. Keragaman alam Indonesia menimbulkan perbedaan genetik pada setiap individunya yang selanjutnya menimbulkan respon produktifitas yang berbeda.

Respon pemanfaatan sumber daya alam Indonesia terhadap produktivitas Ayam Arab sudah banyak diteliti. Salah satunya adalah pemanfaatan Azolla microphylla sebagai salah satu bahan pakan terbarukan pada fase pullet dan layer (Wulandari et al., 2013; 2015). Penggunaan Azolla microphylla dapat memberikan efek positif terhadap produktivitas. Akan tetapi, evaluasinya belum mampu melihat efisiensi pemanfaatan ransum secara maksimal. Oleh karena itu dalam penelitian ini, peneliti ingin mengevaluasi berbagai potensi bahan pakan lokal yang dapat memaksimalkan produktivitas Ayam Arab. Pemanfaatan yang maksimal bertujuan agar tidak menimbulkan efek yang negatif bagi lingkungan dan ekonomi peternak.

Pemanfaatan maksimal yang dimaksudkan adalah berupa standar kebutuhan Ayam Arab agar produktivitas maksimal. Sejauh ini, standar pemberian pakan Ayam Arab di kalangan peternak masih berorientasi pada kebutuhan ayam petelur leghorn ataupun ayam kampung. Padahal, genetik Ayam Arab tidak dapat 
disamaratakan dengan unggas lainnya, sehingga penggunaan standar kebutuhannya pun tidak dapat disamaratakan.

Berdasarkan kondisi tersebut maka diperlukan evaluasi penggunaan berbagai macam bahan pakan yang diberikan secara free feeding choice. Sistem free feeding choice ini berprinsip pada "keinginan" ayam dalam pemenuhan kebutuhan. Ayam akan secara natural mengontrol keinginan dalam mengkonsumsi. Layaknya seorang manusia, apabila manusia merasa perlu asupan sumber protein, maka ia akan segera mengkonsumsi bahan pangan sumber protein. Begitu pula dengan ternak, ternak akan melakukan hal yang sama seperti manusia. Prinsip inilah yang diterapkan dalam sistem free feeding choice (Fanatico et al., 2013; Hossain et al., 2014; Racheal, 2014). Penelitian ini diharapkan mampu meningkatkan produktivitas dan menghasilkan standar yang digunakan sebagai patokan kebutuhan Ayam Arab fase pullet sampai layer.

\section{MATERI DAN METODE}

Penelitian menggunakan 100 ekor Ayam Arab betina pullet umur 14 minggu dengan bobot badan seragam. Bahan pakan yang dibutuhkan bekatul, pollard, jagung kuning, meat bone meal, tepung ikan, bungkil kedelai, $\mathrm{CaCO}_{3}$, tepung Azolla microphylla, dan kulit kerang. Peralatan yang digunakan adalah kandang baterai, tempat ransum dan minum termodifikasi, timbangan.

Ransum yang diberikan terdiri dari 3 macam ransum (Tabel 1). Ransum T1, ransum rujukan oleh Wulandari et al. (2013). Ransum T2, ransum rujukan oleh Wulandari et al. (2015). Ransum T3, ransum termodifikasi sistem free feeding choice. Sistem free feeding choice ini memberikan kelonggaran ternak dalam memilih bahan pakan yang akan dikonsumsi. Ransum dan air minum yang diberikan secara ad libitum.

Tabel 1. Komposisi Ransum Perlakuan Ayam Arab Pullet - Layer

\begin{tabular}{lccc}
\hline \multirow{2}{*}{ Bahan Pakan } & \multicolumn{3}{c}{ Perlakuan } \\
\cline { 2 - 4 } & T1 & T2 & T3 \\
\hline Jagung Kuning & 40,00 & 35,00 & Ad libitum \\
Pollard & - & - & Ad libitum \\
Bekatul & 29,00 & 33,50 & Ad libitum \\
Tepung Ikan & - & - & Ad libitum \\
Meat Bone Meal & 6,50 & 5,00 & Ad libitum \\
Bungkil Kedelai & 9,00 & 16,75 & Ad libitum \\
Tepung Azolla microphylla & 6,00 & 6,00 & Ad libitum \\
CaCO3 & 3,00 & 1,25 & Ad libitum \\
Cangkang kerang & 6,00 & 2,5 & Ad libitum \\
Top Mix & 0,50 & 0,50 & Ad libitum \\
\hline
\end{tabular}

Penelitian dilakukan di kandang percobaan Fakultas Peternakan, Universitas Boyolali di Kalisidi, Ungaran. Penelitian diawali dengan pengadaan bahan pakan, persiapan ternak, pembuatan kandang modifikasi dan perlengkapan 
pemeliharaan. Perlakuan dilakukan selama 8 minggu pada ayam yang dipelihara di kandang baterai dan kandang termodifikasi FFC sesuai penelitian dari Olver dan Malan (2000).

Penimbangan sisa ransum dilakukan sekali sehari pada waktu pagi hari sebelum pemberian pakan hari berikutnya. Data produktivitas (hen day production) dilakukan dengan pencatatan jumlah peneluran pertama pada setiap perlakuan. Pada akhir penelitian, beberapa sampel telur dianalisis protein kasar.

Data yang didapatkan selanjutnya dilakukan analisis statistik rancangan acak lengkap, apabila terdapat perbedaan yang nyata dilanjutkan analisis duncan.

\section{HASIL DAN PEMBAHASAN}

\section{Konsumsi Ransum, Protein Kasar, Serat Kasar}

Data konsumsi ransum ayam Arab periode pullet hingga bertelur yang diberi ransum dengan metode free feeding choice, rujukan Wulandari et al. (2013), dan rujukan Wulandari et al. (2015) disajikan pada Tabel 2 dan Ilustrasi1. Analisis statistik untuk konsumsi ransum nyata $(P \leq 0,05)$ dipengaruhi oleh perlakuan.

Tabel 2. Konsumsi ransum, protein kasar, dan serat kasar ayam arab dengan ransum metode free feeding choice, rujukan Wulandari et al. (2013), dan rujukan Wulandari et al. (2015)

\begin{tabular}{lccc}
\hline \multicolumn{1}{c}{ Parameter } & $\begin{array}{c}\text { Free Feeding } \\
\text { Choice }\end{array}$ & $\begin{array}{c}\text { Ransum } \\
\text { Wulandari et al. } \\
\text { (2015) }\end{array}$ & $\begin{array}{c}\text { Ransum } \\
\text { Wulandari et al. } \\
\text { (2013) }\end{array}$ \\
\hline $\begin{array}{l}\text { Konsumsi ransum } \\
\text { Konsumsi Protein }\end{array}$ & $100,22^{\mathrm{a}}$ & $98,92^{\mathrm{a}}$ & $97,80^{\mathrm{b}}$ \\
$\begin{array}{l}\text { Kasar } \\
\text { Konsumsi Serat }\end{array}$ & 18,63 & 14,77 & 16,47 \\
Kasar & $12,40^{\mathrm{b}}$ & $12,20^{\mathrm{b}}$ & $17,75^{\mathrm{a}}$ \\
\hline
\end{tabular}

Superskrip berbeda pada setiap baris yang sama menunjukkan perbedaan yang nyata $(\mathrm{P} \leq 0,05)$

Konsumsi ransum pada ayam yang diberi ransum dengan menggunakan metode FFC tidak berbeda nyata dengan ayam yang diberi ransum Wulandari et al. (2015). Namun konsumsi ransum pada ayam yang diberi ransum Wulandari et al. (2013) berbeda nyata dengan konsumsi ransum menggunakan Wulandari et al. (2015) dan metode FFC. Perbedaan jumlah konsumsi diakibatkan karena faktor metode pemberian pakan. Ternak yang diperlakukan dengan metode free feeding choice (FFC) memiliki konsumsi ransum yang lebih tinggi dibanding perlakuan lainnya. Hal ini dikarenakan adanya palatabilitas bahan pakan yang berbeda-beda, keinginan dan kebebasan ternak dalam memilih bahan pakan, dan perbedaan kebutuhan nutrisi yang berbeda-beda dalam waktu yang sama. Palatabilitas ransum merupakan salah satu faktor pendukung konsumsi ransum (Nicol et al., 2002; Donoughuel et al., 2012). 


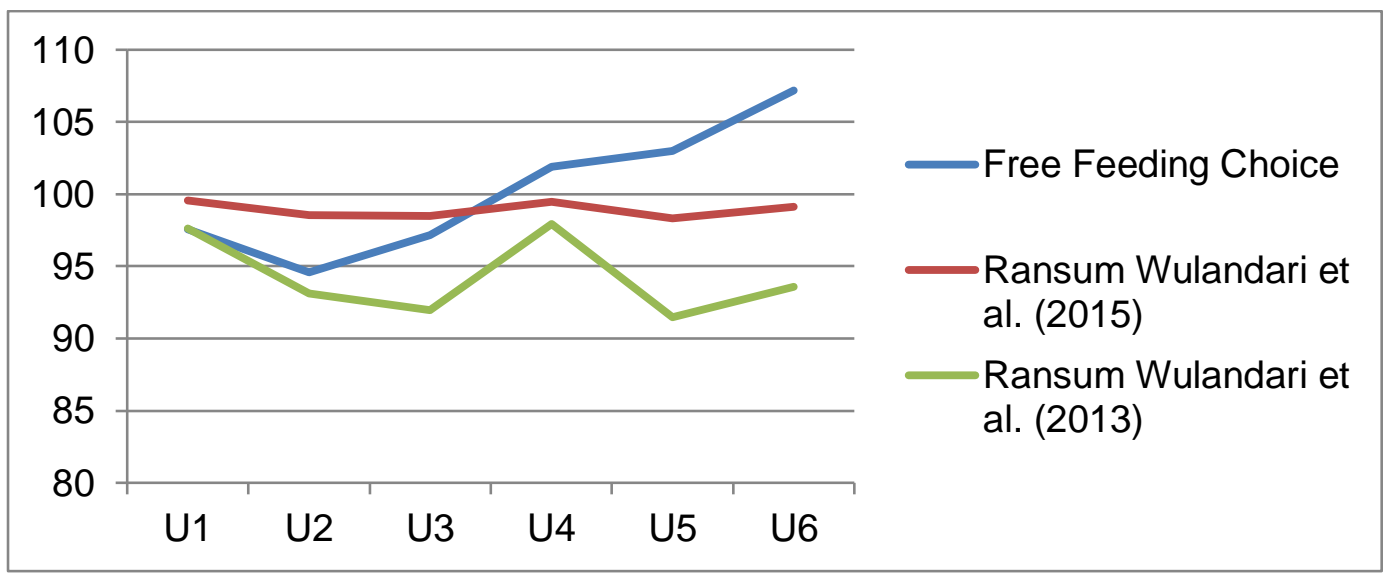

Ilustrasi 1. Grafik Konsumsi Ransum Ayam Arab Periode Pullet Hingga Bertelur yang Diberi Ransum dengan Metode Free Feeding Choice, Rujukan Wulandari et al. (2013), dan Rujukan Wulandari et al. (2015)

Secara numerik, selisih antara konsumsi ransum metode FFC dengan ransum Wulandari et al. (2015) sama dengan selisih antara konsumsi ransum Wulandari et al. (2015) dengan ransum Wulandari et al. (2013). Selisih yang sama ini menimbulkan perbedaan notasi. Hal ini dimungkinkan karena perbedaan jumlah nutrisi yang dikonsumsi, terutama energi metabolis (EM) dan protein kasar (PK). Konsumsi ransum metode FFC tidak berbeda nyata dengan konsumsi ransum Wulandari et al. (2015), hal ini dimungkinkan karena penyajian ransum Wulandari et al. (2015) sesuai dengan kebutuhan ternak, meskipun jumlah ransum setiap ulangan pada perlakuan FFC tidak dapat diseragamkan.

Kuantitas konsumsi ransum yang ditemukan pada ayam yang diberi ransum Wulandari et al. (2013) lebih sedikit dibanding FFC maupun Wulandari et al. (2015). Hal ini dimungkinkan karena kandungan PK nya lebih tinggi dibanding ransum FFC maupun Wulandari et al. (2015). Ransum Wulandari et al. (2013) memiliki PK sebesar 17,47\%, sedangkan ransum Wulandari et al. (2015) 14,97\%, dan ransum metode FFC yang beragam. Nilai kualitas PK ini menyebabkan adanya perbedaan konsumsi ransum. Menurut Swatson et al. (2002) bahwa konsumsi ransum pada unggas lebih sedikit bila ransum mempunyai kandungan protein yang tinggi dan asam amino yang lebih seimbang. Menurut teori "aminostatic Mellinkoff" peningkatan konsentrasi asam amino plasma dapat menurunkan nafsu makan karena merangsang pusat kenyang di otak yang sensitif terhadap konsentrasi asam amino. Bagian otak yang sensitif terhadap level asam amino adalah area posterma dan anterior piriform cortex (Schwartz, 2000).

Data konsumsi protein kasar ayam Arab periode pullet hingga bertelur yang diberi ransum dengan metode free feeding choice, rujukan Wulandari et al. (2013), dan rujukan Wulandari et al. (2015) disajikan pada Tabel 1 dan Ilustrasi 2. Analisis statistik untuk konsumsi protein ransum tidak nyata dipengaruhi oleh perlakuan.

Konsumsi protein kasar pada ayam yang diberi ransum Wulandari et al. (2015) dan Wulandari et al. (2013) dihitung berdasarkan perhitungan antara kandungan protein kasar ransum dengan jumlah konsumsi ransum. Sedangkan Konsumsi protein kasar pada ayam yang diberi ransum dengan metode FFC dihitung berdasarkan jumlah konsumsi masing-masing bahan pakan dikalikan dengan kandungan protein kasar masing-masing bahan pakan. 




Ilustrasi 2. Konsumsi Protein Kasar Ayam Arab Periode Pullet Hingga Bertelur yang Diberi Ransum dengan Metode Free Feeding Choice, Rujukan Wulandari et al. (2013), dan Rujukan Wulandari et al. (2015)

Berbeda dengan tren jumlah konsumsi ransum dengan konsumsi protein kasar. Pada konsumsi ransum menghasilkan data yang nyata dipengaruhi oleh perlakuan, akan tetapi pada konsumsi protein kasar tidak dipengaruhi perlakuan. Hal ini disebabkan oleh kebutuhan protein kasar yang sama dalam umur yang seragam.

Secara numerik terdapat perbedaan jumlah konsumsi protein kasar yang cukup banyak, yakni kurang lebih 2 g/ekor/hari. Ternak yang mengkonsumsi dengan metode FFC lebih banyak dibanding dengan ternak lainnya. Hal ini dimungkinkan disebabkan oleh adanya kebebasan ternak dalam memilih. Kebebasan ini dimungkinkan karena adanya rasa ayam dalam memenuhi kebutuhannya. Kebebasan dalam mengkonsumsi bahan pakan ini pada akhirnya dapat diartikan menjadi dua, yakni kebebasan yang sesuai dengan kebutuhan atau kebebasan yang menyimpang dalam artian perilaku dalam pemilihan pakan. Perilaku dalam pemiilihan pakan ini terjadi dalam penelitian ini. Perilaku yang dijumpai adalah ayam lebih memilih pakan yang berbentuk butiran dibanding yang berbentuk mess.

Secara numerik, ternak yang diberi ransum Wulandari et al. (2013) lebih tinggi dibanding Wulandari et al. (2015) hal ini disebabkan oleh perbedaan konsumsi ransum dan kandungan protein ransum yang sangat berbeda. Kandungan protein ransum pada Wulandari et al. (2013) adalah $14,93 \%$ dan pada Wulandari et al. (2015) sebesar 17,47\%. Konsumsi ransum ayam pada kedua perlakuan ini selisihnya kurang lebih $1 \mathrm{gram} / \mathrm{ekor} / \mathrm{hari}$, akan tetapi menghasilkan selisih konsumsi protein kasar kurang lebih 2 gram/ekor/hari.

Data konsumsi serat kasar ayam Arab periode pullet hingga bertelur yang diberi ransum dengan metode free feeding choice, rujukan Wulandari et al. (2013), dan rujukan Wulandari et al. (2015) disajikan pada Tabel 1 dan Ilustrasi 3. Analisis statistik untuk konsumsi serat kasar ransum nyata $(P<0,05)$ dipengaruhi oleh perlakuan.

Konsumsi serat kasar pada ayam yang diberi perlakuan FFC tidak berbeda nyata dengan ayam yang diberi ransum Wulandari et al. (2015), tetapi berbeda nyata dengan ayam yang diberi perlakuan ransum Wulandari et al. (2013). Konsumsi serat kasar pada ayam yang diberi perlakuan ransum Wulandari et al. (2013) berbeda nyata dengan ayam yang diberi perlakuan FFC dan ayam yang 
diberi ransum Wulandari et al. (2015). Perbedaan ini dikarenakan kandungan serat kasar yang tinggi dalam ransum Wulandari et al. (2013) yakni sebesar 18,83\%.

Berdasarkan Ilutrasi 3, terlihat bahwa terjadi garis yang curam pada grafik konsumsi serat kasar pada ayam yang diberi ransum dengan metode FFC. Kecuraman ini dimungkinkan terjadi pemilihan bahan pakan. Pada ketiga ransum perlakuan ini menggunakan bahan pakan Azolla microphylla. Sesuai dengan kondisi yang terjadi saat penelitian, bahwa daya konsumsi Azolla microphylla pada ayam dengan metode FFC sangat rendah, yakni 1,44-6,48 gram/ekor/ayam. Kandungan serat kasar Azolla microphylla yakni 47,85\%. Analisa yang didapat bahwa ayam lebih tidak menyukai Azolla microphylla dibandingkan bahan pakan lainnya. Serat kasar pada ransum memiliki fungsi negatif dan positif. Fungsi ini tergantung pada kandungan NDF dan ADF sebagai komponen dari serat kasar. Fungsi negatif yakni mengikat nutrien lainnya sehingga membentuk garam yang tidak mudah diserap. Sedangkan fungsi positifnya adalah mempercepat gerak peristaltik saluran pencernaan, sehingga memaksimalkan sekresi enzim dari dinding pencernaan. Menurut Has et al. (2014) bahwa serat kasar memiliki fungsi dalam perkembangan saluran perncernaan, dan memaksimalkan fungsi enzim pencernaan dalam mencerna ransum.

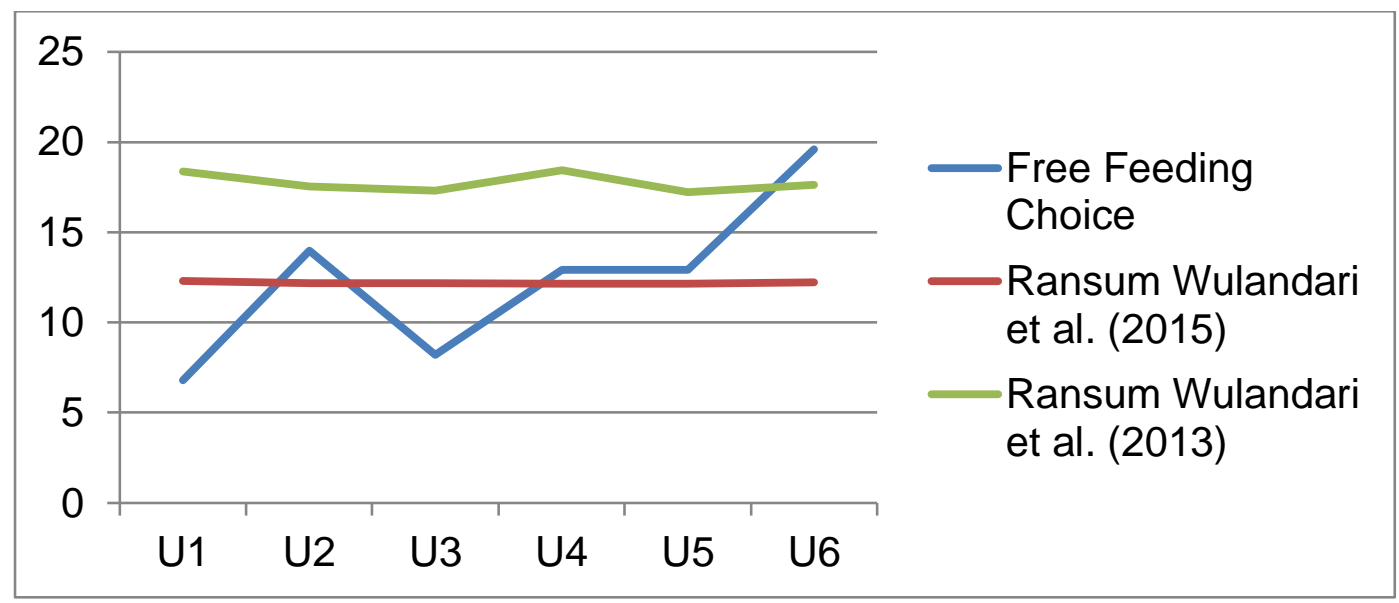

Ilustrasi 3. Konsumsi Serat Kasar Ayam Arab Periode Pullet Hingga Bertelur yang Diberi Ransum dengan Metode Free Feeding Choice, Rujukan Wulandari et al. (2013), dan Rujukan Wulandari et al. (2015)

\section{Hen House Production}

Data hen house production diambil berdasarkan perbandingan jumlah populasi ayam percobaan dengan produksi telur selama masa percobaan. Ilustrasi 5. merupakan data grafik HHS dimana terdapat peningkatan produksi telur. 


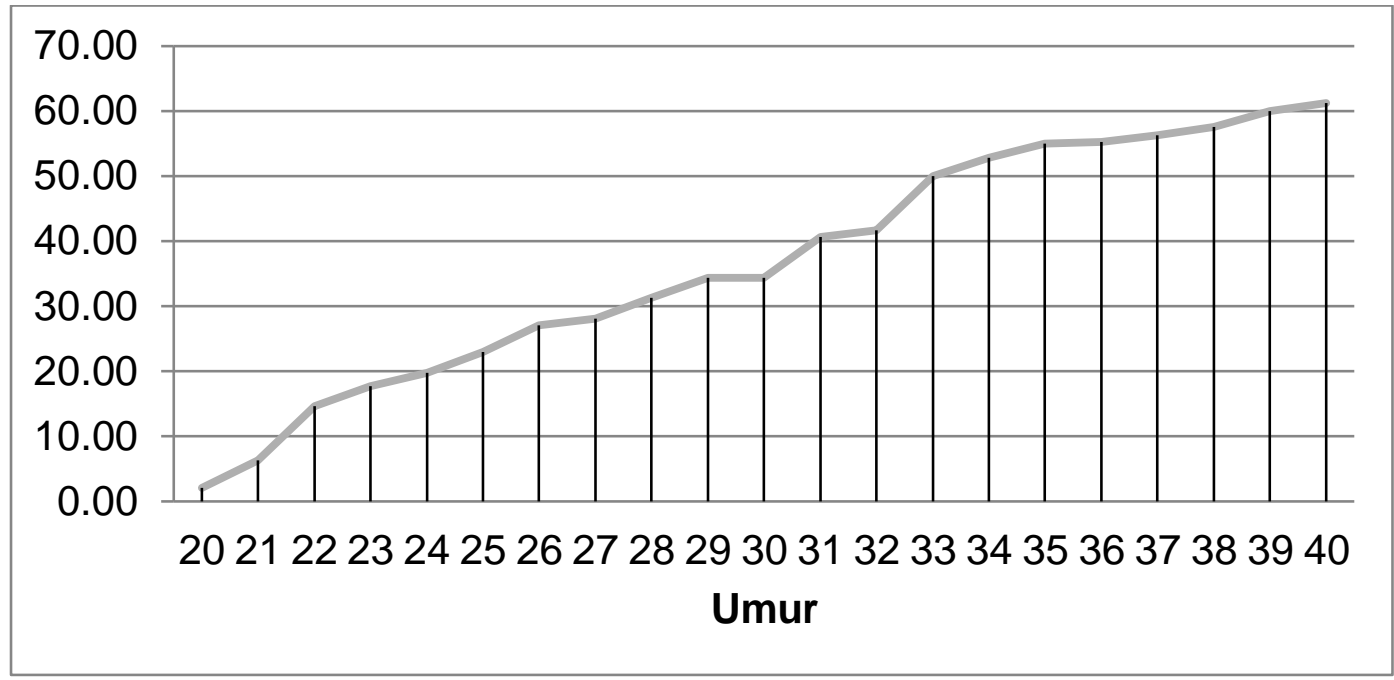

Ilustrasi 4. Hen House Production Ayam Arab Periode Pullet Hingga Bertelur yang Diberi Ransum dengan Metode Free Feeding Choice, Rujukan Wulandari et al. (2013), dan Rujukan Wulandari et al. (2015)

Hen house production dari data llustrasi 5 menunjukkan bahwa ransum yang diberikan dalam penelitian ini tidak memberikan efek yang negatif terhadap produktivitas ayam arab. Akan tetapi, umur mulai bertelurnya tidak seragam. Ini dimungknkan karena kualitas pullet ternak. Pullet ayam arab yang dipilih merupakan kualitas bibit nomer 2 dengan HDP maksimal $70 \%$.

\section{Kualitas Protein Kasar Telur}

Data kandungan protein telur ayam Arab periode pullet hingga bertelur yang diberi ransum dengan metode free feeding choice, rujukan Wulandari et al. (2013), dan rujukan Wulandari et al. (2015) disajikan pada Tabel 3 dan llustrasi 5. Analisis statistik untuk konsumsi ransum nyata $(\mathrm{P}<0,05)$ dipengaruhi oleh perlakuan.

Tabel 3. Kualitas protein kasar telur ayam arab dengan ransum metode free feeding choice, rujukan Wulandari et al. (2013), dan rujukan Wulandari et al. (2015)

\begin{tabular}{ccc}
\hline Free Feeding Choice & $\begin{array}{c}\text { Ransum Wulandari et al. } \\
\text { (2015) }\end{array}$ & $\begin{array}{c}\text { Ransum Wulandari et al. } \\
\text { (2013) }\end{array}$ \\
\hline $3,59^{\mathrm{a}}$ & $3,49^{\mathrm{b}}$ & $5,43^{\mathrm{a}}$ \\
\hline
\end{tabular}

Superskrip berbeda pada setiap baris yang sama menunjukkan perbedaan yang nyata $(P \leq 0,05)$

Kandungan protein telur pada ayam yang diberi perlakuan ransum rujukan Wulandari et al. (2013) nyata lebih tinggi dibanding metode pemberian FFC dan rujukan Wulandari et al. (2015). Akan tetapi Kandungan protein telur pada ayam yang diberi perlakuan ransum rujukan Wulandari et al. (2013) tidak berbeda nyata dengan kandungan protein telur dengan metode pemberian FFC. Data ini sejalan dengan tren konsumsi protein, dimana ayam yang mengkonsumsi lebih banyak protein kasar dalam ransum menghasilkan berat telur dan persentase kandungan 
protein kasar yang lebih tinggi. Kandungan telur pada ayam yang diberi ransum rujukan Wulandari et al. (2015), nyata lebih rendah dibandingkan yang lainnya. Hal ini dumungkinkan karena adanya pengaruh jumlah konsumsi protein yang rendah.



Ilustrasi 5. Kandungan Protein Kasar Telur Ayam Arab Periode Pullet Hingga Bertelur yang Diberi Ransum dengan Metode Free Feeding Choice, Rujukan Wulandari et al. (2013), dan Rujukan Wulandari et al. (2015)

Disamping itu, perbandingan jumlah konsumsi serat kasar pada ketiga perlakuan sangat terlihat. Konsumsi serat kasar pada ayam yang diberi ransum rujukan Wulandari et al. (2013) lebih tinggi dibanding perlakuan lainnya akan tetapi menghasilkan kandungan protein telur yang lebih tinggi dibanding yang mengkonsumsi serat kasar lebih sedikit. Hal ini dimungkinkan bahwa sebagian serat kasar sumbangan dari Azolla microphylla pada ransum Wulandari et al. (2013) tidak menjadikan hal yang negatif. Serat kasar dapat terdiri dari ADF dan NDF, dimana ADF merupakan salah satu fraksi dari karbohidrat yang menimbulkan efek positif bagi pencernaan. ADF merupakan salah satu fraksi penyusun dari polisakarida. Dimana polisakarida ini yang membantu mikroflora positif dalam mencerna nutrisi hingga maksimal.

\section{KESIMPULAN}

Metode pemberian pakan dengan free feeding choice tidak memberikan efek negatif pada ternak. Disamping itu, pemberian pakan dengan metode free feeding choice dapat mendukung animal welfare secara maksimal.

\section{UCAPAN TERIMA KASIH}

Penulis berterima kasih atas bantuan dana yang diberikan oleh Direktorat Riset dan Pengabdian Masyarakat yang telah memberikan hibah penelitian dosen pemula tahun anggaran 2019. 


\section{DAFTAR PUSTAKA}

Donoghue, A. M., J. R. Moyle, J. M. Burke, A. Fanatico, J. A. Mosjidis, T. Spencer, K. Arsi, I. Reyes-Herrera, A. Woo-Ming, and D. J. Donoghue. 2012. Palatability of tannin-rich sericea lespedeza fed to broilers. J. Appl. Poult. Res. $21: 891-896$.

Fanatico, A. C., V. B. Brewer, C. M. Owens-Hanning, D. J. Donoghue, and A. M. Donoghue. Free-choice feeding of free-range meat chickens. J. Appl. Poult. Res. 22 :750-758.

Has, H., A. Napirah, A. Indi. 2014. Efek peningkatan serat kasar dengan penggunaan daun murbei dalam ransum broiler terhadap persentase bobot saluran pencernaan. JITRO 1 (1) : 63-66.

Hossain, M. A., A. F. Islam., P. A. Iji. 2014. Effect of production phase on growth, enzyme activities and feed selection of broilers raised on vegetable protein diet. Asian Australas. J. Anim. Sci. 27 (11) : 1593-1599.

Nicol, C. J., C. M. Sherwin, and C. M. Heyes. 2002. Social learning influences the preferences of domestic hens for novel food. J. Anim. Behav. 6 (5) : 933942.

Olver, M. D., dan D. D. Malan. 2000. The effect of choice-feeding from 7 weeks of age on production characteristics of laying hens. South African J. Anim. Sci. $30(2): 110-114$.

Racheal, A.O. 2014. Effects Of Different Feeding Strategies on Foraging Ability and Nutrient Digestibility of a Slow Growing Organic Broiler Genotype. Intership Report. Denmark: Aarhus University.

Scwartz. 2000. Intisari Prinsip-Prinsip IImu Bedah. Buku Kedokteran, Jakarta

Swatson, H. K., R. Gous, P. A. lji dan R. Zarrinkalam. 2002. Effect of dietary protein level, amino acid balance and feeding level on growth, gantrointestinal tract and mucosal structure of the small intestine in broiler chickens. Anim. Res. $51: 501-515$

Wulandari, E. C., H. I. Wahyuni, dan N. Suthama. 2015. Buangan nitrogen dan fosfor ayam arab yang diberi ransum dengan imbangan kalsium dan fosfor berbeda. Prosiding Seminar Nasional Teknologi dan Agribisnis Peternakan (Seri III) Pengembangan Peternakan Berbasis Sumberdaya Lokal untuk Menghadapi Masyarakat Ekonomi ASEAN (MEA), Purwokerto. Hal. 226-229

Wulandari, E. C., R. H. Prawitasari, N. Suthama, W. Murningsih, V.D. Yunianto, I. Estiningdriati and $\mathrm{H}$. I. Wahyuni. 2013. Contribution of lysine and calcium of azolla microphylla on egg shell calcium deposition in arab hen. 3rd AINI International Seminar. The Role of Nutrition and Feed in Supporting Self Sufficient In Animal Products, Food Safety And Human Welfare, Padang. Hal. 129-13. 